\title{
ADAPTING DRY CASK STORAGE FOR AGING AT A GEOLOGIC REPOSITORY
}

\author{
Charlotta Sanders (Bechtel SAIC) \\ 1180 Town Center Drive \\ Las Vegas, NV 89144 \\ charlotta_sanders@ymp.gov
}

\author{
Darby Kimball (Bechtel National, Inc.) \\ 50 Beale Street \\ San Francisco, CA 94105 \\ dskimbal@bechtel.com
}

\section{ABSTRACT}

A Spent Nuclear Fuel (SNF) Aging System is a crucial part of operations at the proposed Yucca Mountain repository in the United States. Incoming commercial SNF that does not meet thermal limits for emplacement will be aged on outdoor pads. U.S. Department of Energy SNF will also be managed using the Aging System. Proposed site-specific designs for the Aging System are closely based upon designs for existing dry cask storage (DCS) systems. This paper evaluates the applicability of existing DCS systems for use in the SNF Aging System at Yucca Mountain.

The most important difference between existing DCS facilities and the Yucca Mountain facility is the required capacity. Existing DCS facilities typically have less than 50 casks. The current design for the aging pad at Yucca Mountain calls for a capacity of over 2,000 casks (20,000 MTHM) [1]. This unprecedented number of casks poses some unique problems. The response of DCS systems to off-normal and accident conditions needs to be re-evaluated for multiple storage casks. Dose calculations become more complicated, since doses from multiple or very long arrays of casks can dramatically increase the total boundary dose. For occupational doses, the geometry of the cask arrays and the order of loading casks must be carefully considered in order to meet ALARA goals during cask retrieval. Due to the large area of the aging pad, skyshine must also be included when calculating public and worker doses.

The expected length of aging will also necessitate some design adjustments. Under 10 CFR 72.236, DCS systems are initially certified for a period of 20 years [2]. Although the Yucca Mountain facility is not intended to be a storage facility under 10 CFR 72, the operational life of the SNF Aging System is 50 years [1]. Any cask system selected for use in aging will have to be qualified to this design lifetime.
These considerations are examined, and a summary is provided of the adaptations that must be made in order to use DCS technologies successfully at a geologic repository.

Keywords: dry cask storage, aging, spent nuclear fuel, Yucca Mountain.

\section{INTRODUCTION}

A Spent Nuclear Fuel (SNF) Aging System is a crucial part of operations at the proposed Yucca Mountain repository in the United States. Incoming commercial SNF that does not meet thermal limits for emplacement will be aged on outdoor pads. U.S. Department of Energy SNF will also be managed using the Aging System. Proposed designs for the Aging System are closely based upon designs for existing dry cask storage (DCS) systems. This paper evaluates the applicability of existing DCS systems for use in the SNF Aging System at Yucca Mountain.

\section{NOMENCLATURE}

$\begin{array}{ll}\text { ALARA } & \text { As Low As Reasonably Achievable } \\ \text { BWR } & \text { boiling water reactor } \\ \text { CFR } & \text { U.S. Code of Federal Regulations } \\ \text { DCS } & \text { Dry Cask Storage } \\ \text { DOE } & \text { U.S. Department of Energy } \\ \text { DPC } & \text { dual-purpose canister (storage and transport) } \\ \text { HAM } & \text { horizontal aging module } \\ \text { ISFSI } & \text { Independent Spent Fuel Storage Installation } \\ \text { MTHM } & \text { metric tons of heavy metal } \\ \text { PWR } & \text { pressurized water reactor } \\ \text { SNF } & \text { Spent Nuclear Fuel }\end{array}$


During emplacement operations, the Yucca Mountain facility will be receiving commercial SNF and DOE SNF from around the United States. Upon arrival at Yucca Mountain, not all of the spent nuclear fuel will meet thermal limits for emplacement. The Aging System was developed to handle and age the commercial SNF with higher heat content until it is suitable for emplacement. U.S. Department of Energy SNF will also be managed using the Aging System.

\section{Aging System Operation}

Commercial SNF from nuclear power plant sites will be shipped to the Yucca Mountain facility either as bare fuel assemblies in a transportation cask, or as canistered fuel assemblies inside a transportation overpack. (The transportation overpack is an enclosure used to provide protection in shipping of a canister.) DOE SNF will be shipped as canistered fuel inside a transportation overpack. The canisters used for transportation of SNF will generally be dualpurpose canisters (DPCs), used for both storage and transportation.

When a handling facility has bare SNF assemblies or vertical DPCs that require aging, the SNF or DPC is placed into vertical aging casks or vertical aging overpacks (thick walled vessels designed to provide protection and shielding during aging). In some cases SNF that requires aging may be transferred to a site-specific disposable canister which is suitable for both storage and long-term disposal; these disposable canisters are also placed into vertical aging overpacks. After all cask closure operations are completed in the processing facility, vertical aging casks are moved to the aging pad by means of a crawler or wheeled transporter designed to handle the vertical aging casks.

When a transportation cask containing a horizontal DPC that requires aging is received at the repository, the cask is taken to the Transportation Cask Receipt /Return Facility where its impact limiters are removed. The transportation overpack with canister inside is then transferred to a special trailer and towed by tractor to the aging pad. On the aging pad, the canister is transferred directly from the overpack into a concrete vault (the HAM) using a hydraulic ram.

Aging casks will be continuously monitored for temperature and pressure while on the aging pad. After the decay heat of the SNF has decreased sufficiently, the SNF will be transferred to a waste package for emplacement.

\section{Aging System Design Requirements}

The design of the Aging System is focused on meeting the following design requirements [1]: The capacity of the Aging System is to be 21,000 MTHM - an initial aging pad of 1,000 MTHM capacity, followed by construction of 5,000 MTHM aging pads as needed. The Aging System must accommodate an expected waste stream received at the repository bounded by the commercial SNF characteristics currently in dry or wet storage systems at reactor plants (including fuel burnup of up to $60,000 \mathrm{MWd} / \mathrm{MTU}){ }^{1}$ The SNF Aging System must be designed for an operational life of 50 years, and the Aging System must also be designed and operated to prevent any credible criticality event from occurring.

\section{Aging System Subsystems}

The Aging System at Yucca Mountain includes three subsystems: the aging casks, the aging pad, and the system used to transport aging casks to and from the aging pad [1]. Although closely based on dry cask storage technologies, the design and safety analysis for these components is ongoing. Information presented here is of a preliminary nature.

Aging casks may be grouped into three categories: a) vertical metal aging casks to accommodate uncanistered commercial SNF (bare assemblies), b) vertical metal or concrete aging overpacks to accommodate canistered commercial and DOE SNF, DPCs, or disposable canisters; and c) concrete horizontal aging modules (HAMs) to accommodate horizontal DPCs. If possible, aging casks will be previouslylicensed DCS designs that have been qualified for use in aging applications at the Yucca Mountain site. ${ }^{2}$

Each aging pad area consists of one to five modular slab units. Each aging pad modular unit can accommodate 1,000 MTHM and has a layout as shown in Fig. 1. Currently, each aging system modular unit is designed to accommodate 20 HAMs and 80 vertical aging casks [1]. Twenty HAMs are arranged in a $2 \times 10$ back-to-back array. The vertical aging casks are stored in a $2 \times 40$ array with a pitch of 13 feet $(4.0$ meters) to 18 feet (5.5 meters) [4]. (All dimensions given in this document are approximate since the design of the HAMs and vertical aging casks and transfer equipment is in the early stages of design development and subject to change.)

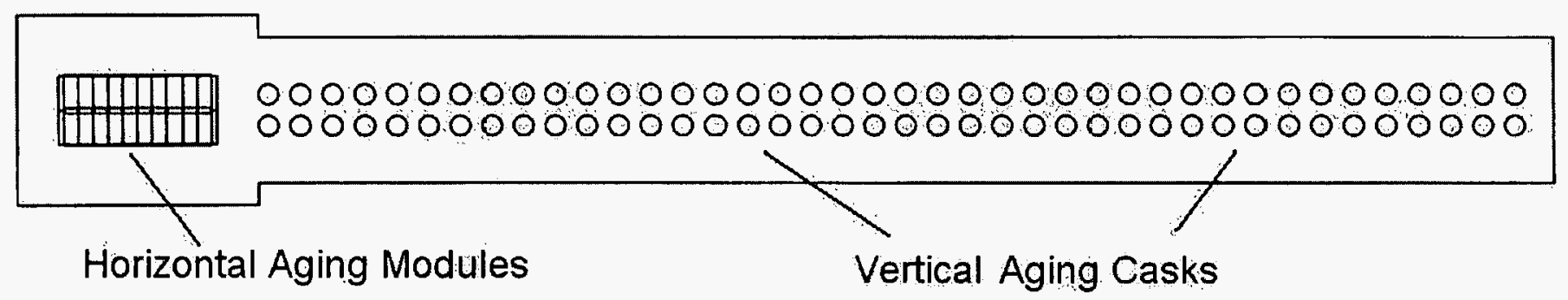

Figure 1 - Typical Modular Aging Pad Unit (100 casks, 1,000 MTHM) 
The aging pad modular unit is a concrete foundation 7 feet (2.1 meters) thick under the cask arrays and 3 feet ( 0.91 meters) thick in the surrounding apron areas [5]. As shown in Fig. 1, there are two rectangular portions: one for the HAM storage array and one for the vertical aging cask storage array. Each of these portions accommodates a cask array surrounded by an apron area of roughly 15 feet (4.6 meters) to 30 feet (9.1 meters) in width. The portion for the HAMs is approximately 135 feet ( 41.1 meters) long by 110 feet ( 33.5 meters) wide. The portion for the vertical aging casks is approximately 750 feet ( 228.6 meters) long by 85 feet ( 25.9 meters) wide. The overall aging pad modular unit is approximately 885 feet $(269.7$ meters) long by 110 feet ( 33.5 meters) wide.

The aging cask transfer subsystem consists of equipment capable of moving a) vertical metal aging casks containing bare SNF assemblies; b) vertical metal or concrete aging overpacks containing a DPC, a site-specific disposable canister, or DOE SNF canisters; and c) a transportation cask or a transfer cask containing a horizontal DPC to and from the aging pads. Operations for moving casks (both vertical and horizontal) are similar to those performed at commercial nuclear plants. A site-specific cask crawler or wheeled transporter will be used for transporting the vertical aging cask. A specially designed 32-wheel horizontal cask transfer trailer towed by a tractor will be used for moving horizontal transportation casks up to the HAM. This trailer will be equipped with a hydraulic ram for transferring the DPC into the HAM.

\section{AGING SYSTEM VS. DRY CASK STORAGE SYSTEMS}

The requirements and design parameters noted above represent several departures from existing DCS designs.

Existing DCS installations contain far fewer numbers of storage casks. Each site typically is licensed for less than 100 storage casks. Two examples are the North Anna Independent Spent Fuel Storage Installation (ISFSI), which is licensed for 57 casks [6] but contains 22 casks at the time of writing, and the Prairie Island ISFSI, which is licensed for 48 casks and currently houses 17 casks [7]. Presently, the Holtec storage system (i.e., HI-STORM) is used at 5 commercial sites in the
U.S. which collectively contain nearly 50 individual storage casks. The NAC storage system is used at 6 commercial sites in the U.S. with a total of over 200 individual storage casks. The Transnuclear storage system is used at 21 commercial sites in the U.S which collectively contain over 250 storage casks, including both metal vertical storage sites and concrete horizontal (NUHOMS canister) storage sites.

The Aging System must also accommodate fuel which is outside the range of parameters handled by existing DCS installations. For example, the maximum PWR fuel assembly expected to be received at the repository is currently [8]:

Maximum enrichment $=5 \%$

Maximum burnup $=80 \mathrm{GWd} / \mathrm{MTU}$

Minimum cooling time $=5 \mathrm{yr}$

Maximum heat output $=2.48 \mathrm{~kW}$ per fuel assembly (The design basis fuel assembly is $4 \%$ enrichment with a burnup of $60 \mathrm{GWd} / \mathrm{MTU}$, a 10 year cooling time, and a maximum heat output of $1.2 \mathrm{~kW}$ per assembly [8].)

Table I gives a summary of the transportation and storage casks currently certified by the NRC for PWR use. (PWR fuel represents a more bounding design case than BWR fuel; aging of BWR fuel is similar but is not addressed in this report.) As shown in the table, no currently certified casks are capable of handling the maximum PWR fuel assembly. Current DCS systems are not licensed to handle up to $5 \mathrm{wt} \%$ enriched fuel and burnups of $80 \mathrm{GWd} / \mathrm{MTU}$.

In addition, existing DCS installations are not certified for long periods of storage. DCS installations are typically licensed as ISFSIs for 20 years of operation with a possibility for extension, as compared to the 50-year design lifetime of the Aging System. The Surry ISFSI (which utilizes Transnuclear TN-32 vertical casks) began operations in 1986 and has the capacity to continue operation throughout the life of the power plant [18]. The same is true for the Prairie Island ISFSI, which began operations in 1993 and whose Unit 1 and 2 Operating Licenses will expire in 2013 and 2014, respectively [7]. Other examples of ISFSIs licensed for 20 year operation include Rancho Seco (using NUHOMS horizontal modules), which began operations in 1999 [19], and North Anna, (using Transnuclear TN-32 vertical casks) which began operations in 1998 [6].

Table I - NRC-Certified PWR Spent Fuel Storage Casks

\begin{tabular}{|c|c|c|c|c|c|c|c|c|}
\hline $\begin{array}{c}\text { Cask Type \& } \\
\text { Model Number }\end{array}$ & $\begin{array}{c}\text { NRC } \\
\text { Certificate } \\
\text { Number }\end{array}$ & $\begin{array}{c}\text { Fuel Type/ } \\
\text { Capacity }\end{array}$ & $\begin{array}{c}\text { Maximum } \\
\text { Enrichment } \\
(\% \text { U-235) }\end{array}$ & $\begin{array}{c}\text { Minimum } \\
\text { Enrichment } \\
(\% \text { U-235) }\end{array}$ & $\begin{array}{c}\text { Burnup } \\
\text { Limit } \\
(\text { MWd/MTU) }\end{array}$ & $\begin{array}{c}\text { Min. } \\
\text { Cooling } \\
\text { Time }\end{array}$ & $\begin{array}{c}\text { Assembly } \\
\text { Thermal } \\
\text { Limit (kW) }\end{array}$ & $\begin{array}{c}\text { Package } \\
\text { Thermal } \\
\text { Limit (kW) }\end{array}$ \\
\hline HI-STAR100 [9] & $72-1008$ & PWR/24 & 4.1 & 3.4 & 42000 & $15 \mathrm{yr}$ & 0.520 & 12.4 \\
\hline TN-32[10] & $72-1021$ & PWR/32 & N/A & 3.5 & 45000 & $7 \mathrm{yr}$ & 0.986 & \\
\hline $\begin{array}{c}\text { NUHOMS-24P } \\
{[11]}\end{array}$ & $72-1004$ & PWR/24 & 4.0 & N/A & 40000 & $6 \mathrm{yr}$ & 1.0 & \\
\hline $\begin{array}{c}\text { HI-STORM 100 } \\
{[12]}\end{array}$ & $72-1014$ & PWR/24 & 4.0 & N/A & 66200 & $5 \mathrm{yr}$ & 1.470 & \\
\hline NAC-UMS [13] & $72-1015$ & PWR/24 & 4.2 & N/A & 45000 & $10 \mathrm{yr}$ & 0.788 & 18.9 \\
\hline NAC-MPC [14] & $72-1025$ & PWR/36 & 3.9 & 3.7 & 36000 & $8.1 \mathrm{yr}$ & 0.347 & 12.5 \\
\hline VSC-24[15] & $72-1007$ & PWR/24 & 3.2 & N/A & 35000 & $5 \mathrm{yr}$ & 1.0 & \\
\hline BNFLW21[16] & $72-1026$ & PWR/21 & 4.6 & N/A & 60000 & $16.9 \mathrm{yr}$ & 1.195 & 25.1 \\
\hline $\begin{array}{c}\text { NUHOMS } \\
\text { Advanced [17] }\end{array}$ & $72-1029$ & PWR/24 & 4.05 & N/A & 45000 & $10 \mathrm{yr}$ & 0.581 & \\
\hline
\end{tabular}


When licensed as an ISFSI, a DCS installation needs to comply with 10 CFR 72 (Licensing Requirements for the Independent Storage of Spent Nuclear Fuel, High-Level Radioactive Waste, and Reactor-Related Greater than Class C Waste) [2]. The Aging System, on the other hand, is not intended to be licensed as an ISFSI but instead will be licensed under 10 CFR 63 (Disposal of High-Level Radioactive Wastes in a Geologic Repository at Yucca Mountain, Nevada) [20].

While the two regulations are similar in many respects, there are some differences. One example is the previously mentioned operating lifetime: the Aging System operational life of 50 years is a design requirement stemming from 10 CFR $63.111(\mathrm{e})(1)[20]$ to preserve the option of retrieving waste starting at anytime up to 50 years after waste emplacement operations are initiated, while DCS installations typically are licensed for 20 years with possible extensions as stated in 10 CFR 72.42(a) and 10 CFR 72.212(a)(3) [2]. Another major difference is that 10 CFR 63 requires a risk-informed, performance-based approach rather than a deterministic approach (as in 10 CFR 72), which affects the seismic design criteria.

\section{CONSIDERATIONS IN DESIGN AND LICENSING OF AN AGING SYSTEM}

The differences between the design and licensing requirements of the Aging System and the typical requirements of a dry cask storage system (detailed in the previous section) have corresponding impacts upon the design and licensing of the Aging System. In order to adapt existing dry cask storage technology for use in the Aging System, several factors must be taken into account.

\section{Radiation Protection and Shielding}

Some important design considerations can be seen in the area of radiation protection and shielding. The Aging System is required to provide radiological protection in accordance with the requirements specified in 10 CFR Part 20 [21] as well as meeting ALARA principles in accordance with 10 CFR Part 63 and 10 CFR Part 20 [1].

In keeping with existing systems licensed under $10 \mathrm{CFR}$ Part 72, the nominal radiation level from the surface of any single vertical site-specific cask or horizontal aging module at a distance of one meter shall not exceed $60 \mathrm{mrem} / \mathrm{hr}(0.60$ $\mathrm{mSv} / \mathrm{hr}$ ). For normal and Category 1 event sequences, the dose to the public beyond the site boundary shall not exceed 15 mrem $(0.15 \mathrm{mSv})$ total effective dose equivalent (TEDE) in one year [1]. No individual located on or beyond the site boundary shall receive a dose of more than 5 rem $(50 \mathrm{mSv})$ TEDE per Category 2 event [1]. In addition, an ALARA goal of 500 $\mathrm{mrem} / \mathrm{yr}(5 \mathrm{mSv} / \mathrm{yr})$ per worker was established [22].

However, the number of casks that the Aging System must accommodate poses some interesting challenges to meeting these radiation protection goals.

When considering a direct radiation dose at the side of a single row of casks, the dose rate is generally dominated by some small number of casks nearest the receptor. The contributions of the further casks are minimal compared to the closer casks due to both distance (air attenuation) and selfshielding by the other casks in the row. The effect of the casks at the ends of the rows becomes more pronounced with increasing distance from the array. Although air attenuation causes the overall dose for any size array to decrease with distance, the ratio of dose rates from a long array as compared to a short array will increase with distance.

A similar effect is seen due to skyshine from large arrays of casks. A recent shielding evaluation [4] examined the effectiveness of a concrete shielding wall in reducing dose rates from the aging pad. This evaluation showed that although a concrete shielding wall taller than the vertical casks would be effective in reducing the lateral radiation dose, the relative benefit provided by the wall lessens with increasing distance from the wall due to air scatter (skyshine). With a $2 \mathrm{ft}(61 \mathrm{~cm})$ thick concrete shielding wall in place, the majority of the dose on the other side is due to skyshine.

Table II shows selected dose calculations for a 1000 MTHM aging pad and a 5000 MTHM aging pad, both shielded and unshielded [4]. For the shield case, a shield wall of 2-ft thick concrete slab was assumed at $40 \mathrm{ft}(12 \mathrm{~m})$ from the outermost row of casks. From these results, we can see that the percent of the dose due to skyshine increases drastically as the size of the aging pad area increases.

Thus, for an aging facility which has row upon row of aging casks in the direction perpendicular to the wall, a shielding wall does not provide any measurable protection from the casks in the middle of the aging pad or from the casks at the far side of the aging pad. In such cases, a wider boundary zone around the aging pad coupled with administrative controls is the most reasonable strategy to control radiation exposure [23].

There are several general categories of Aging System operations. The main operations are transport of horizontal canisters to and from the facility, transport of loaded vertical modules to and from the facility, and transport of empty vertical casks to and from the facility [24], but placement of seismic tie-downs and/or manned surveillance activities may also be required. The dose rate for each operation is comprised of two components: a background dose rate from the casks on the aging pad and an operation-specific dose rate.

In operational practice, the specific placement of the vertical site-specific casks can have a significant impact on average occupational doses. The pitch of the vertical sitespecific casks is the largest factor driving the nature of the doses; a tighter cask spacing results in increased dose rates received by the on-pad worker, while looser cask spacing results in increased boundary dose rates [4].

Current dose rate evaluations performed on the limitingcase cask (casks giving a dose of $60 \mathrm{mrem} / \mathrm{hr}(0.60 \mathrm{mSv} / \mathrm{hr}$ ) at $1 \mathrm{~m}$ from the surface of one single cask) indicate that cask spacing has a significant effect on occupational doses. For a cask spacing of 13 feet ( 4.0 meters), a worker performing cask installation operations will be exposed to a maximum background dose rate of approximately $250 \mathrm{mrem} / \mathrm{hr}(2.5$ $\mathrm{mSv} / \mathrm{hr}$ ) [4]. A worker performing cask surveillance will be exposed to a background dose rate of approximately 100 $\mathrm{mrem} / \mathrm{hr}(1 \mathrm{mSv} / \mathrm{hr})$ [4]. For a cask spacing of 18 feet $(5.5$ meters), the maximum background dose rate for cask installation drops to approximately $200 \mathrm{mrem} / \mathrm{hr}(2 \mathrm{mSv} / \mathrm{hr})$, and the cask surveillance background dose rate drops to roughly $85 \mathrm{mrem} / \mathrm{hr}(0.85 \mathrm{mSv} / \mathrm{hr})$ [4]. 
Table II - Dose Rates as a Function of Distance from Aging Pads

\begin{tabular}{|c|c|c|c|c|c|c|}
\hline & \multicolumn{3}{|c|}{1000 MTHM Aging Pad } & \multicolumn{3}{|c|}{5000 MTHM Aging Pad } \\
\hline $\begin{array}{l}\text { Distance to } \\
\text { nearest } \\
\text { cask row } \\
\text { (m) }\end{array}$ & $\begin{array}{l}\text { Unshielded } \\
\text { dose rate } \\
\text { (mrem } / \mathrm{hr})^{*}\end{array}$ & $\begin{array}{l}\text { Shielded } \\
\text { dose rate } \\
\text { (mrem } / \mathrm{hr} \text { ) }\end{array}$ & $\begin{array}{c}\text { Dose due } \\
\text { to } \\
\text { skyshine } \\
(\%)\end{array}$ & $\begin{array}{c}\text { Unshielded } \\
\text { dose rate } \\
(\mathrm{mrem} / \mathrm{hr})\end{array}$ & $\begin{array}{l}\text { Shielded } \\
\text { dose rate } \\
(\mathrm{mrem} / \mathrm{hr})\end{array}$ & $\begin{array}{c}\text { Dose due } \\
\text { to } \\
\text { skyshine } \\
(\%)\end{array}$ \\
\hline 20 & $1.80 \mathrm{E}+01$ & $1.49 \mathrm{E}+00$ & $8.28 \%$ & $2.26 \mathrm{E}+01$ & $4.62 \mathrm{E}+00$ & $20.44 \%$ \\
\hline 30 & $1.09 \mathrm{E}+01$ & $1.40 \mathrm{E}+00$ & $12.84 \%$ & $1.49 \mathrm{E}+01$ & $4.35 \mathrm{E}+00$ & $29.19 \%$ \\
\hline 40 & $7.39 \mathrm{E}+00$ & $1.13 E+00$ & $15.29 \%$ & $1.09 \mathrm{E}+01$ & $3.77 \mathrm{E}+00$ & $34.59 \%$ \\
\hline 50 & $5.42 \mathrm{E}+00$ & 9.43E-01 & $17.40 \%$ & $8.52 \mathrm{E}+00$ & $3.26 \mathrm{E}+00$ & $38.26 \%$ \\
\hline 60 & $4.05 \mathrm{E}+00$ & 7.83E-01 & $19.33 \%$ & $6.70 E+00$ & $2.80 E+00$ & $41.79 \%$ \\
\hline 70 & $3.18 \mathrm{E}+00$ & $6.70 \mathrm{E}-01$ & $21.07 \%$ & $5.45 \mathrm{E}+00$ & $2.44 E+00$ & $44.77 \%$ \\
\hline 80 & $2.34 \mathrm{E}+00$ & 5.77E-01 & $24.66 \%$ & $4.39 E+00$ & $2.17 E+00$ & $49.43 \%$ \\
\hline 90 & $1.88 \mathrm{E}+00$ & 4.46E-01 & $23.72 \%$ & $3.83 E+00$ & $1.94 \mathrm{E}+00$ & $50.65 \%$ \\
\hline 100 & $1.47 E+00$ & $3.76 \mathrm{E}-01$ & $25.58 \%$ & $3.21 \mathrm{E}+00$ & $1.72 \mathrm{E}+00$ & $53.58 \%$ \\
\hline 200 & $2.53 E-01$ & $8.45 \mathrm{E}-02$ & $33.40 \%$ & 7.24E-01 & 4.84E-01 & $66.85 \%$ \\
\hline 300 & $6.25 E-02$ & 2.07E-02 & $33.12 \%$ & 2.31E-01 & 1.62E-01 & $70.13 \%$ \\
\hline 400 & 1.81E-02 & $6.11 \mathrm{E}-03$ & $33.76 \%$ & $8.14 \mathrm{E}-02$ & $5.96 \mathrm{E}-02$ & $73.22 \%$ \\
\hline 500 & 5.49E-03 & $1.90 \mathrm{E}-03$ & $34.61 \%$ & 2.91E-02 & 2.17E-02 & $74.57 \%$ \\
\hline
\end{tabular}

The time required to complete various operations must also be considered. The maximum speed of the site-specific transporter is 0.5 miles per hour $(0.22 \mathrm{~m} / \mathrm{s})$ [1]. Given the dimensions of the aging pad, it will take the transporter a minimum of 10 minutes merely to travel from the edge to the center of the aging pad. The total time to transport an aging cask to the aging pad has been estimated as 160 minutes, with approximately 20 minutes being within the boundary fence of the aging pad [24]. In addition to transport, the time to emplace a vertical site-specific canister is estimated at 105 minutes [24]. Based on these values, the "worst-case" emplacement of a single aging cask in a location near the center of the aging pad could result in a worker dose of more than 325 mrem ( 3.25 $\mathrm{mSv}$ ).

Naturally, the worker dose will not be this high for the majority of operations. Currently, not enough information on the actual spent fuel to be aged on the aging pad is known to develop a quantitative loading scheme. Once actual fuel parameters are known, the loading scheme could be selected to minimize doses. For example, placing the hottest fuel in locations furthest from occupied areas will minimize dose rates to workers in those areas. Careful planning of operations will reduce doses to workers performing duties on the aging pad itself. The placement sequence and location of casks could be chosen to maximize shielding by surrounding structures and minimize time near already-placed casks. Consideration could also be given to aging pad loading operations so that a cooled cask ready for removal is not surrounded by recently-placed casks.

\section{Accident and Hazard Analysis}

The differences between the Aging System design requirements and those of a DCS installation also have ramifications for accident and hazard analysis. As mentioned previously, 10 CFR 63 (under which the Aging System will be licensed) requires a risk-informed, performance-based approach. Therefore, the design bases, including applicable event sequences for which the aging system is designed, must be identified using probabilistic risk assessment techniques. The ISFSI licensing regulations (10 CFR 72) are based on a deterministic approach.

The number of casks, and the need to accommodate fuel beyond the limits currently licensed for the contents of those casks, manifest as additional considerations both for criticality safety and for hazard analysis.

Criticality analyses and hazard analyses must demonstrate that neutronic interaction between the casks is not a concern. Calculations have been performed with an infinite array of storage casks that are fully flooded inside (limiting conditions) with a variety of external environments at various spacings to investigate neutronic interaction between casks [25]. It was concluded that under these conditions there is no neutronic interaction between casks, as the flooded interior effectively isolates the casks from one another. Under dry conditions, neutronic interactions may be possible (though under normal dry conditions, the reactivity of the casks is so low that criticality is not a concern). Off- normal conditions (e.g., tipovers, tornadoes, missiles) have a small potential to cause geometric rearrangement of the casks relative to one another. This has been considered and judged to be a beyond Category 2 event (not credible, or less than one chance in 10,000 of occurring). 
As part of the license procedure for ISFSIs under $10 \mathrm{CFR}$ 72 [2], safety analyses must be performed to show that the storage casks can handle external hazards. To license a cask for aging, it must be demonstrated that the presence of multiple casks do not pose any concerns.

Design basis extreme wind speeds, tornadoes and corresponding missile spectrums have been established for the aging pad [26]. These established parameters indicate that small targets (e.g., a single cask) are screened out from tornado wind strike and missile strike. However, due to the size of the entire aging pad, tornado missiles cannot be screened out based on a risk-informed application of tornado missile impact probability calculations. As a result, structures must be designed to withstand the design basis missile spectrums [26].

Airspace-related accidents have also been considered due to the numerous military and commercial airspace activities surrounding the Yucca Mountain. Defensible screening criteria based on airport crash tables [27] and crash distance criteria were developed. It was concluded that airspace activities within these various flight corridors that are located outside of the screening criteria do not pose a credible hazard to the repository [28]. Some airspace activities, however, were not able to be screened out and could potentially pose a hazard to the repository. These activities, which include small attack/fighter military aircraft, helicopters, general aviation aircraft, etc., will be further analyzed to determine the potential and consequences for an airspace-related accident impacting multiple casks [28].

In addition, a design requirement will provide for a barrier surrounding the aging pads that would not collapse or be penetrated by an aircraft crash [29]. The design of the aircraft protection barrier has not been finalized but is expected to be a structure of metal precast concrete confining panels backfilled with soil material or tunnel muck at least $20 \mathrm{ft}(6.10 \mathrm{~m})$ high and approximately $30 \mathrm{ft}(9.14 \mathrm{~m})$ thick [1]. Studies of Boeing 747-400 and Boeing 767-400 impacts into transportation casks, storage casks, and similar concrete structures show no breach $[30,31]$.

Seismic design requirements for the larger aging pad are more stringent than for a typical ISFSI. The aging system components will be designed for seismic loads of $1.2 \mathrm{~g}$ peak horizontal acceleration and $0.9 \mathrm{~g}$ peak vertical spectral acceleration at $5 \%$ damping, based on a design basis ground motion from a 2,000-year return period earthquake. Currently most of the licensed DCS systems do not meet these seismic requirements.

To address seismic hazards, the aging pads will be equipped with cask anchoring systems for the vertical casks, if required. Since it has not been shown by analysis at this time that unanchored site-specific casks are precluded from tip over for all credible seismic and missile events, a conceptual anchoring system was devised [1].

The seismic design of the aging pad slab is accomplished using a method which takes into account the design basis ground motion peak ground accelerations in the horizontal and vertical directions. The resulting seismic forces and moments on the aging slab are combined with the dead and live loads and used to determine concrete pad thickness, reinforcing quantities, and reinforcement spacing.

\section{System Design Features}

Lastly, the differences between the Aging System design requirements and those of a DCS installation have an impact on basic system design features. Some of these design differences are illustrated here.

The high number of casks per modular aging pad unit requires a much longer slab that those featured in existing DCS installations. As a result, the calculations for slab thickness and reinforcement requirements, which involve calculating forces and moments acting on the slab, are affected. The aging pad slabs [5] feature cold joints which are intended to isolate sections of the slab from each other. This keeps expansion and contraction due to temperature from cracking the slab, as well as minimizing the impact of phenomena such as earthquakes and frost heave.

Since aging times are longer than DCS storage times, adaptation of a DCS system must include justification that the extended design lifetime does not pose any material degradation concerns.

Lastly, there are indications that some of the design limits will need to be revisited for higher burnup or higher enrichment fuel [32]. Higher burnups mean thermally hotter fuel, and cask licensing must accommodate the expected temperatures.

\section{SUMMARY}

In summary, adapting existing dry cask storage systems for use in an aging facility requires careful consideration. The differing design requirements of an aging facility (increased number of casks to age, increased limits on cask contents, and differences in the licensing process) each contribute to changes that have to be made in order to use existing DCS systems for aging purposes. The preparation of radiation protection and shielding calculations, accident and hazard analyses, and system design documents all have to take these differing design requirements into account. Fundamentally, however, the technologies are very similar, and DCS 'systems can be adequately adapted for use by the Yucca Mountain Aging System.

\section{ACKNOWLEDGMENTS}

This study was supported in part by Bechtel SAIC Company, LLC and the Yucca Mountain Project. Support was also provided by Bechtel National, Inc. and Bechtel Systems \& Infrastructure, Inc. 
[14] Thompson 2000. "Docket No. 72-1025, Submittal of NAC-MPC FSAR, Revision 0 (TAC No. L22907)." Letter

[1] BSC (Bechtel SAIC Company) 2005. SNF Aging System Description Document. 170-3YD-HA00-00100-000004. Las Vegas, Nevada: Bechtel SAIC Company, April 2005.

[2] NRC (Nuclear Regulatory Commission) 2004. "Energy: Licensing Requirements for the Independent Storage of Spent Nuclear Fuel, High-Level Radioactive Waste, and Reactor-Related Greater than Class C Waste", Code of Federal Regulations, 10 CFR 72. Washington, DC: Office of Federal Register National Archives and Records Administration, U.S. Government Printing Office, revised as of January 1, 2004.

[3] Cogema 2004. Aging Facility Area Dose Rate Classification. COGEMA-C0115-EN-CLC-0016. Las Vegas, Nevada: Cogema Inc., May 2004.

[4] BSC (Bechtel SAIC Company) 2004. Dose Rate Evaluations for Spent Nuclear Fuel Aging Areas. 170-00CHAP0-00400-000-00A. Las Vegas, Nevada: Bechtel SAIC Company, December 2004.

[5] BSC (Bechtel SAIC Company) 2004. Spent Nuclear Fuel Aging Area 1000 MTHM Aging Module Concrete Plan and Sections. 170-DB0-HAP0-00101-000-00B. Las Vegas, Nevada: Bechtel SAIC Company, June 2004.

[6] Virginia Electric and Power Company 2004. North Anna Independent Spent Fuel Storage Final Safety Analysis Report, Revision 4. Richmond, Virginia: Virginia Electric and Power Company, June 2004.

[7] Nuclear Management Company 2001. Prairie Island Independent Spent Fuel Storage Safety Analysis Report, Revision 9. Welch, Minnesota: Nuclear Management Company, October 2001.

[8] BSC (Bechtel SAIC Company) 2004. PWR Source Term Generation and Evaluation. 000-00C-MGR0-00100000-00B. Las Vegas, Nevada: Bechtel SAIC Company, May 2004.

[9] Holtec International 1996. Topical Safety Analysis Report for the Holtec International Storage, Transport and Repository Cask System (HI-STAR 100 Cask System), Nonproprietary Version. Holtec Report HI-941184, Rev. 4. Two volumes. Marlton, New Jersey: Holtec International, September 1996.

[10] Hunter 2002. "TN-32 FSAR Update per 10CFR72.248; Erratum Docket 72-1021." Letter from I. Hunter (Transnuclear) to U.S. Nuclear Regulatory Commission, May 13, 2002, E-19479a, with enclosures, May 2002.

[11] Vectra Technologies 1995. Safety Analysis Report for the Standardized NUHOMS $\otimes$ Horizontal Modular Storage System for Irradiated Nuclear Fuel. NUH-003, Rev. 3A. Volume 1. Docket 72-1004. San Jose, California: Vectra Technologies, June 1995.

[12] HOLTEC International 2002. Final Safety Analysis Report for the Holtec International Storage and Transfer Operation Reinforced Module Cask System (Hi-Storm 100 Cask System). HOLTEC Report HI-2002444. Two volumes. NRC Docket No. 72-1014. Marlton, New Jersey: HOLTEC International, September 2002.

[13] Thompson 2000. "Docket No. 72-1015, Submittal of NAC-UMS FSAR, Revision 0 (TAC No. L22511)." Letter from T.C. Thompson (NAC) to the NRC, December 21, 2000, with enclosure, December 2000. from T.C. Thompson (NAC) to the NRC, May 23, 2000, with enclosure, May 2003.

[15] Hodges 1998. "Confirmatory Action Letter 97-7001, Technical Evaluation, Docket No: 72-1007." Washington, D.C.: U.S. Nuclear Regulatory Commission. Accessed November 2, 1999, November 1999.

[16] BNFL Fuel Solutions 2001. FuelSolutions ${ }^{\text {TM }}$ Storage System Final Safety Analysis Report, Revision 0. WSNF-220. Docket No. 72-1026. Scotts Valley, California: BNFL Fuel Solutions, February 2001.

[17] Chopra 2003. "Final Safety Analysis Report (FSAR) for the Standard Advanced NUHOMS $\otimes$ Horizontal Modular Storage for Irradiated Nuclear Fuel, Revision 0." Letter from U.B. Chopra (Transnuclear) to M.J. Ross-Lee (NRC), March 19, 2003, with enclosures, March 2003.

[18] Virginia Electric and Power Company 2004. Surry Independent Spent Fuel Storage Final Safety Analysis Report, Revision 16. Richmond, Virginia: Virginia Electric and Power Company, June 2004.

[19] Sacramento Municipal Utility District 2000. Rancho Seco Independent Spent Fuel Storage Final Safety Analysis Report (IFSAR), Revision 0. Sacramento, California: Sacramento Municipal Utility District, November 2000.

[20] NRC (Nuclear Regulatory Commission) 2004. "Disposal of High-Level Radioactive Wastes in a Geologic Repository at Yucca Mountain, Nevada", Code of Federal Regulations, 10 CFR 63. Washington, DC: Office of Federal Register National Archives and Records Administration, U.S. Government Printing Office, revised as of January 1, 2004.

[21] NRC (Nuclear Regulatory Commission) 2004. "Standards for Protection Against Radiation", Code of Federal Regulations, 10 CFR 20. Washington, DC: Office of Federal Register National Archives and Records Administration, U.S. Government Printing Office, revised as of January 1, 2004.

[22] BSC (Bechtel SAIC Company) 2004. Shielding Evaluation for Spent Nuclear Fuel Aging Areas. 170-00CHAP0-00200-000-00A. Las Vegas, Nevada: Bechtel SAIC Company, May 2004.

[23] Cogema 2004. Aging Facility ALARA Evaluation. COGEMA-C0115-RP-04-003. Las Vegas, Nevada: Cogema Inc., April 2004.

[24] Cogema 2004. Aging-Related Dose Assessment. COGEMA-C0115-EN-CLC-0015. Las Vegas, Nevada: Cogema Inc., May 2004.

[25] BSC (Bechtel SAIC Company) 2004. Aging Facility Criticality Safety Calculations. 170-00C-HA0000100-000-00B. Las Vegas, Nevada: Bechtel SAIC Company, September 2004.

[26] BSC (Bechtel SAIC Company) 2004. Extreme Wind/Tornado/Tornado Missile Hazard Analysis. 000-00CWHS0-00100-000-00B. Las Vegas, Nevada: Bechtel SAIC Company, November 2004.

[27] DOE (Department of Energy) 1996. DOE Standard, Accident Analysis for Aircraft Crash into Hazardous Facilities. DOE-STD-3014-96. Washington, D.C.: U.S. Department of Energy, October 1996.

[28] BSC (Bechtel SAIC Company) 2005. Identification of Aircraft Hazards. 000-30R-WHS0-00100-000-005. Las Vegas, Nevada: Bechtel SAIC Company, March 2005. 
[29] BSC (Bechtel SAIC Company) 2005. Frequency Analysis of Aircraft Hazards for License Application. 00000C-WHS0-00200-000-00C. Las Vegas, Nevada: Bechtel SAIC Company, 2005.

[30] McGough, M.S. and Pennington, C.W. 2002. "Plane Tough Storage." Nuclear Engineering International, Pages 24-26. Sutton, Surrey, England: Reed Business Publications, 2002.

[31] Nuclear Energy Institute 2002. "Deterring Terrorism: Aircraft Crash Impact Analyses Demonstrate Nuclear Power Plant's Structural Strength." Washington, D.C.: Nuclear Energy Institute. Summary of report online at http://www.nei.org/documents/eprinuclearplantstructuralstudy2 00212.pdf, accessed June 2005.

[32] Argonne National Laboratory 1998. Extending Dry Storage of Spent LWR Fuel For Up To 100 Years. ANL/CMT/CP-96494. Chicago, Illinois: University of Chicago, November 1998.

'Eventually, some fuel having burnups greater than 60,000 MWd/MTU may be discharged by the reactors and delivered to the repository. The aging cask systems for these higher burnup assemblies will be addressed at a future time and may require some additional analysis or redesign of existing systems.

${ }^{2}$ Vertical systems to be examined for use at the aging facility may include, but are not limited to, the Transnuclear TN-32, TN-68, BNFL W21/W74, Holtec HI-STAR, Holtec HISTORM, NAC MPC, and/or NAC UMS [3]. Horizontal systems to be examined for use at the aging facility may include, but are not limited to, the NUHOMS 24P, 52B, 61BT, and/or 24PT1 [3]. 